\title{
The effects of inhibitors of vacuolar acidification on the release of Listeria monocytogenes from phagosomes of Caco-2 cells
}

\author{
MARIA PIA CONTE, GLORIA PETRONE, CATIA LONGHI, PIERA VALENTI*, R. MORELLI†, FABIANA \\ SUPERTI† and LUCILLA SEGANTI
}

Microbiology Institute, University of Rome, La Sapienza, *Microbiology Institute, II University of Naples and †Department of Ultrastructures, National Institute of Health, Rome, Italy

\begin{abstract}
To evaluate the role of the acidic pH of phagosomes on the invasive ability and fate of Listeria monocytogenes within host cells, entry and replication of this gram-positive bacterium in a human enterocyte-like cell line (Caco-2) were investigated by a combination of biochemical and ultrastructural approaches. The effects of inhibitors of vacuolar acidification - the lipophilic weak base ammonium chloride, the carboxylic ionophore monensin and the vacuolar proton ATPase inhibitor bafilomycin $A_{1}-$ on the bacterial invasion pathway were analysed. These agents, which raise the intracellular vesicle acidic $\mathrm{pH}$ of living cells by different mechanisms, affected $L$. monocytogenes replication in Caco-2 cells. Bacteria internalised by bafilomycin-treated cells were unable to escape from phagosomes, as demonstrated by electronmicroscopy. The results provide evidence that low $\mathrm{pH}$ is required for efficient intracellular growth of $L$. monocytogenes.
\end{abstract}

\section{Introduction}

Listeria monocytogenes is an intracellular, facultative, gram-positive bacterium that causes serious and sometimes fatal infections in pregnant women, neonates and immunocompromised patients [1]. Most outbreaks of listeriosis are clearly associated with the ingestion of contaminated food and there is evidence that the intestine is the usual site of entry of $L$. monocytogenes $[2,3]$.

This micro-organism can enter and multiply in professional and non-professional phagocytes $[4,5]$ and its invasion strategy in enterocyte-like cells has been well characterised $[6,7]$. Each step of the invasive process of $L$. monocytogenes is controlled by different genes [5,8]. Entry into epithelial cells is mediated by internalin, an $80-\mathrm{kDa}$ bacterial protein coded by the inlA chromosomal gene, interacting with an unknown receptor on the cell surface [9]. Once inside the phagosome, $L$. monocytogenes produces the exotoxin listeriolysis $\mathrm{O}$, a $58-\mathrm{kDa}$ protein coded by the hly gene, which participates in the lysing of the phagolysosomal membrane allowing the invading bacterium free access to the host cytoplasm [10-12].

Received 12 April 1995; revised version accepted 31 Oct. 1995.
Then a $90-\mathrm{kDa}$ bacterial protein, coded by the $\operatorname{act} \mathrm{A}$ gene, induces actin polymerisation, leading to bacterial movement, eventually spreading to adjacent cells $[13,14]$.

Listeriolysin needs a low $\mathrm{pH}$ for its activity in vitro [15], and it has been demonstrated recently that phagosome acidification of murine macrophages unequivocally occurs during infection by $L$. monocytogenes [16]. Nevertheless, it has also been reported that weak bases do not prevent $L$. monocytogenes or Bacillus subtilis expressing listeriolysin gaining access to the host cytoplasm $[17,18]$.

Since acidification of vesicles is considered to be an important part of several endocytic pathways [19] and the role of phagosome acidic $\mathrm{pH}$ on the invasion and the fate of $L$. monocytogenes within host cells remains controversial, entry and replication of this microorganism into a human enterocyte-like cell line (Caco2 cells) were studied by a combination of biochemical and ultrastructural approaches. The effects of different inhibitors of vacuolar acidification - the lipophilic weak base ammonium chloride, the carboxylic ionophore monensin and the antibiotic bafilomycin $A_{1}$ on the invasion pathway and intracellular replication of a $L$. monocytogenes wild-type strain were studied. All these agents, raising the intracellular vesicle acidic $\mathrm{pH}$ by different mechanisms [20-22], affected $L$. 
monocytogenes intracellular replication. Moreover, by electron microscopy, bacteria internalised in bafylomycin-treated Caco-2 cells were shown to be unable to escape from phagosomes.

\section{Materials and methods}

\section{Bacterial strains and growth conditions}

L. monocytogenes L37, a clinical isolate provided by Dr P. Aureli (Istituto Superiore Sanità, Rome, Italy) and L. monocytogenes Bof 299 EGDsm $^{r}$ provided by Dr P. Cossart (Institut Pasteur, Paris, France) were the wildtype strains used. The strains were subcultured routinely on Listeria Selective Agar Base (LSAB, Oxoid) and grown in Brain Heart Infusion Broth (BHI, Oxoid). The haemolytic activity of bacterial strains was assessed as described previously [23].

\section{Cell cultures}

The human colon carcinoma cell line Caco-2 (kindly provided by Dr Bernardini, Department of Cellular Biology and Development, University La Sapienza, Rome, Italy) and epithelioid carcinoma of human cervix cells (HeLa S3) were cultured in minimum essential medium (Eagle's MEM) as described previously $[23,24]$.

\section{Infection of cells}

The method described by Gaillard et al. [6] with minor modifications was used for cell infection. Caco-2 and $\mathrm{HeLa}$ cells were trypsinised $48 \mathrm{~h}$ and $24 \mathrm{~h}$ before infection, respectively, and the cell concentration was adjusted to $2 \times 10^{5}$ cells $/ \mathrm{ml}$. Semi-confluent cell monolayers grown without antibiotics in Eagle's MEM were inoculated with bacterial suspensions (100 bacteria/cell) in logarithmic phase, corresponding to a subculture of an overnight culture incubated for $60 \mathrm{~min}$ at $37^{\circ} \mathrm{C}$. After an infection period of $1 \mathrm{~h}$ at $37^{\circ} \mathrm{C}$, the cells were washed extensively with PBS and $1 \mathrm{ml}$ of fresh medium containing gentamicin $5 \mu \mathrm{g} / \mathrm{ml}$ was added to each well. At different time points, cells were lysed by the addition of $0.5 \mathrm{ml}$ of cold Triton X$1000.1 \%$, diluted in $\mathrm{H}_{2} \mathrm{O}$ and plated on LSAB to determine the number of viable intracellular bacteria (cfu/ml). Data concerning invasion assays were derived from four independent experiments, performed in triplicate. The mean values and standard deviations were determined for each assay. In some experiments, infected monolayers were fixed in methanol and stained with Giemsa. The number of cells invaded and of internalised bacteria/invaded cell were evaluated by random counting of 400 cells.

\section{Chemicals}

The following inhibitors of vacuolar acidification (all from Sigma) were used: ammonium chloride $\left(\mathrm{NH}_{4} \mathrm{Cl}\right)$ (a lipophilic weak base), monensin (a carboxylic ionophore) and bafilomycin $A_{1}$ (an inhibitor of vacuolar type $\mathrm{H}^{+}$-ATPase). $\mathrm{NH}_{4} \mathrm{Cl}$ was dissolved as a stock solution in water, monensin in absolute methanol and bafilomycin $A_{1}$ in dimethylsulphoxide. Serial dilutions of these drugs were incubated for different time intervals (up to $24 \mathrm{~h}$ ) with cells or bacteria to establish the non-cytotoxic, non-bactericidal and nonbacteriostatic concentrations: $20 \mathrm{mM} \mathrm{NH}_{4} \mathrm{Cl}, \quad 0.1 \mu \mathrm{M}$ monensin and $0.1 \mu \mathrm{M}$ bafilomycin $\mathrm{A}_{1}$ did not affect the viability of either bacteria (as determined by viable counts) or eukaryotic cells (as determined by neutral red uptake assays).

\section{Transmission electronmicroscopy}

Infected and uninfected cell monolayers were fixed in cacodylate-buffered glutaraldehyde $3 \%(0.1 \mathrm{M}, \mathrm{pH} 7.2)$ for $1 \mathrm{~h}$ at room temperature and post-fixed in $\mathrm{OsO}_{4} 1 \%$ for $1 \mathrm{~h}$. Fixed specimens were dehydrated through a graded series of ethanol solutions. They were then scraped off the surface of culture dishes and embedded in Agar 100 (Agar AIDS, Cambridge, Essex). Serial ultra-thin sections were collected on 200-mesh grids and then counterstained with uranyl acetate and lead citrate, and examined by electron microscopy (Zeiss 902 at $80 \mathrm{kV}$ ). To investigate the number of $L$. monocytogenes in bafilomycin-treated and untreated infected cells, 50 separate cytoplasmic areas for both cases to be studied were selected at random, each area being $20 \mu \mathrm{m}^{2}$. Bacteria within selected areas were counted and the average number of $L$. monocytogenes/ $20 \mu \mathrm{m}^{2}$ was determined for each of the groups of 50 areas. Statistical analysis was by Student's $t$ test.

\section{Results}

Invasion of epithelial cell lines by wild-type $L$. monocytogenes strains L37 and EGD

Both L. monocytogenes strains possessed haemolytic activity and were able to invade Caco-2 and HeLa S3 cells, although $L$. monocytogenes $\mathrm{L} 37$ showed a higher invasion efficiency than L. monocytogenes EGD (Table 1). To study the intracellular replication of these strains, after infection for $1 \mathrm{~h}$, a bactericidal concentration of gentamicin $(5 \mu \mathrm{g} / \mathrm{ml})$ was added to monolayers to kill extracellular bacteria and, at different time

Table 1. Invasion of epithelial cell lines by L. monocytogenes wild-type strains

\begin{tabular}{lcc}
\hline Bacterial strains & Host cells & Percentage of invasion* \\
\hline L. monocytogenes EGD & Caco-2 & $4.3(0.2)$ \\
L. monocytogenes L37 & Caco-2 & $7.0(0.3)$ \\
L. monocytogenes EGD & HeLa S3 & $4.6(0.4)$ \\
L. monocytogenes L37 & HeLa S3 & $6.2(0.2)$ \\
\hline
\end{tabular}

Data are means (SD) for four experiments.

*Values represent the number of internalised bacteria and are expressed as the ratio of intracellular cfu/inoculum cfu $\times 100$. 
intervals, infected cells were lysed to determine the number of viable intracellular bacteria. The results of these experiments showed that $L$. monocytogenes L37 was capable of multiplication in both cell lines and its growth rate was similar to that of $L$. monocytogenes EGD (data not shown). The following experiments were undertaken only with $L$. monocytogenes L37 strain and Caco-2 cells.

\section{Effects of inhibitors of vacuolar acidification on L. monocytogenes L37 entry and growth in Caco- 2 cells}

The requirement of a low-pH step during L. monocytogenes invasion of Caco-2 cells was investigated with three inhibitors of vacuolar acidification of living cells $\left(\mathrm{NH}_{4} \mathrm{Cl}\right.$, monensin and bafilomycin $\left.\mathrm{A}_{1}\right)$ which act on the acidification of intracellular vesicles by different mechanisms. $\mathrm{NH}_{4} \mathrm{Cl}$, a lipophilic weak base, enters the vesicles readily and to accumulates, preventing endosome acidification [20]; the monovalent ion-selective ionophore monensin facilitates the transmembrane exchange principally of sodium ions for protons [21]; the antibiotic bafilomycin $A_{1}$ is a powerful and selective inhibitor of the vacuolar proton-ATPases [22].

These compounds were tested in preliminary experiments with both bacteria and Caco-2 cells. $\mathrm{NH}_{4} \mathrm{Cl}$ (20 mM), $0.1 \mu \mathrm{M}$ monensin and $0.1 \mu \mathrm{M}$ bafilomycin $\mathrm{A}_{1}$ were added to Caco-2 cells for $30 \mathrm{~min}$ before the addition of the bacterial inoculum and also kept in contact during the infection step $\left(1 \mathrm{~h}\right.$ at $\left.37^{\circ} \mathrm{C}\right)$ and the treatment with gentamicin. Infected monolayers were lysed after different time intervals to determine the number of viable intracellular bacteria.

Fig. 1 indicates that the invasion efficiency of bacteria in Caco-2 cells exposed to the vacuolar acidification inhibitors was not significantly affected. In fact, $2 \mathrm{~h}$ after the addition of bacteria, the susceptibility of $\mathrm{NH}_{4} \mathrm{Cl}$ - and monensin-treated colonic cells to infection with L. monocytogenes L37 was similar to that of untreated cells and, in bafilomycin-treated cells, the bacterial internalisation was slightly decreased. These results indicate that endosome acidification is not required for the internalisation step of the listeria invasion pathway. When incubation of Caco-2 cells with the drugs was prolonged, the intracellular growth of $L$. monocytogenes exhibited a completely different behaviour from that observed in untreated controls. The number of intracellular bacteria within cells exposed to the agents determined at 4 and $6 \mathrm{~h}$ after infection remained unaltered whereas bacteria multiplied in untreated cells.

These experiments were also performed in HeLa cells and intracellular bacteria were evaluated by viable counts and Giemsa-stained preparations. Results were consistent with those presented in Fig. 1.

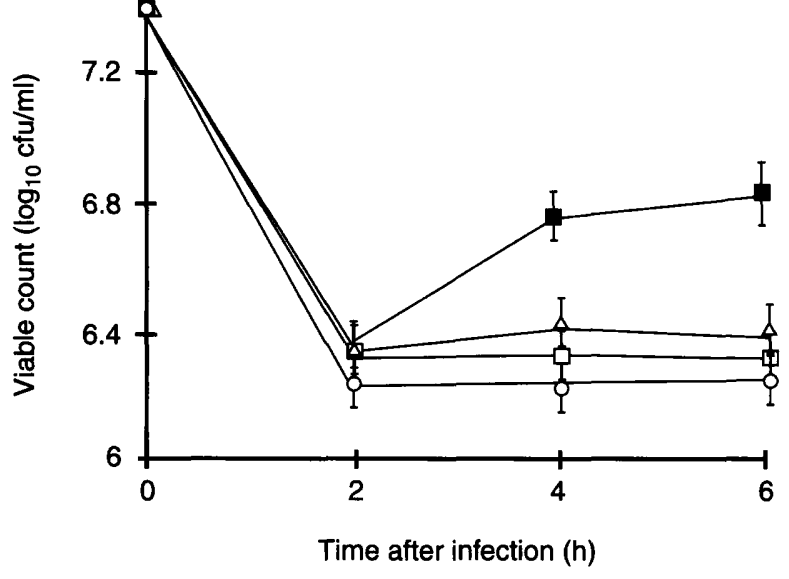

Fig. 1. Effect of inhibitors of vacuolar acidification on invasion of Caco-2 cells by $L$. monocytogenes $\mathrm{L} 37$. The cells were infected at a multiplicity of infection of 100 bacteria/cell for $1 \mathrm{~h}$ at $37^{\circ} \mathrm{C}$. The agents were added to Caco-2 cells for $30 \mathrm{~min}$ before the addition of bacterial inoculum, during the infection step $\left(1 \mathrm{~h}\right.$ at $\left.37^{\circ} \mathrm{C}\right)$ and during treatment with gentamicin. At different time intervals after the incubation in gentamicin containing medium, Caco-2 cells were lysed to determine the number of viable intracellular bacteria. Results are expressed as the mean $\log _{10}$ of viable bacteria/well. Data represent the average of five independent experiments performed in duplicate. Error bars represent SD. $\square$, untreated Caco-2 cells; $\square$, Caco-2 cells treated with $20 \mathrm{mM} \mathrm{NH}_{4} \mathrm{Cl} ; \Delta$, Caco-2 cells treated with $0.1 \mu \mathrm{M}$ monensin; $\bigcirc$, Caco- 2 cells treated with $0.1 \mu \mathrm{M}$ bafilomycin $\mathrm{A}_{1}$.

From these results it would appear that multiplication of $L$. monocytogenes in Caco- 2 cells was blocked in the presence of the different compounds that elevated the vacuolar $\mathrm{pH}$. To establish which phase of the invasion pathway was affected, drugs were incubated with the cells before, during and after infection. No inhibition of invasion was observed when the drugs were pre-incubated with the cells and removed before the addition of bacterial inoculum, nor when they were added only during the infection step.

To assess which step of the intracellular infective cycle was affected, experiments were performed in which the compounds were added before $(30 \mathrm{~min})$, during the infection step $(1 \mathrm{~h})$, and together with gentamicin immediately after the monolayer infection for different periods of time $(1,3,5$ and $7 \mathrm{~h})$. After incubation the compounds were removed and fresh medium containing gentamicin was added to cell monolayers and the degree of intracellular bacterial multiplication was determined $7 \mathrm{~h}$ after the infection step.

The results of the kinetics of action of inhibitors of vacuolar acidification on $L$. monocytogenes replication, shown in Fig. 2, are expressed as the percentage of cfu reduction by comparison with untreated controls. Fig. 2 shows that $\mathrm{NH}_{4} \mathrm{Cl}$, monensin and bafilomycin $A_{1}$ strongly inhibited bacterial multi- 
plication and that this action took place in the earliest stages of the invasion process. In other experiments, after the bacterial infection stage, Caco-2 infected cells were incubated in medium containing gentamicin for different lengths of time (1, 3 and $5 \mathrm{~h}$ ) before the addition of the agents, and in these conditions the intracellular replication of bacteria was not affected (results not shown).

\section{Electron microscopic examination of bafilomycin $A_{1}$-treated and untreated $L$. monocytogenes- infected cells}

As the inhibitor of vacuolar proton-ATPases had the greatest effect on bacterial multiplication, electron microscopy was used to investigate the fate of $L$. monocytogenes in bafilomycin $\mathrm{A}_{1}$-treated and untreated Caco-2 cells. L. monocytogenes was incubated for $1 \mathrm{~h}$ with Caco- 2 cells pretreated for $30 \mathrm{~min}$ at $37^{\circ} \mathrm{C}$ with $0.1 \mu \mathrm{M}$ bafilomycin $\mathrm{A}_{1}$ at a multiplicity of infection of 100 bacteria/cell in the presence or absence of the agent. Samples were taken after extensive washes at the end of a re-incubation period of $1 \mathrm{~h}$ and $3 \mathrm{~h}$ in fresh medium containing gentamicin $5 \mu \mathrm{g} / \mathrm{ml}$ either with or without $0.1 \mu \mathrm{M}$ bafilomycin $\mathrm{A}_{1}$.

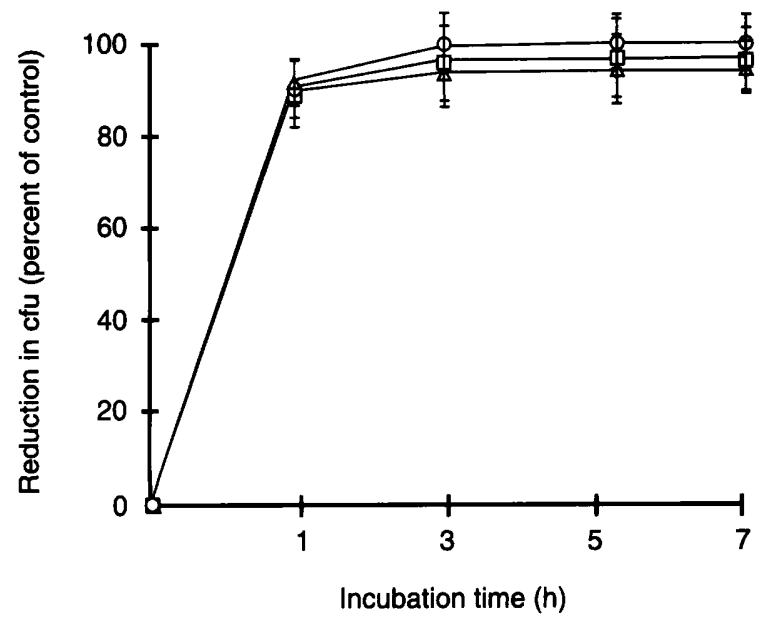

Fig. 2. Effect of inhibitors of vacuolar acidification on intracellular multiplication of $L$. monocytogenes. The cells were infected at a multiplicity of infection of 100 bacteria/cell for $1 \mathrm{~h}$ at $37^{\circ} \mathrm{C}$. The agents were added to the cells for $30 \mathrm{~min}$ before the addition of bacterial inoculum, during the infection step $\left(1 \mathrm{~h}\right.$ at $\left.37^{\circ} \mathrm{C}\right)$, and together with gentamicin immediately after the monolayer infection for different periods of time $(1,3,5$ and $7 \mathrm{~h}$ ). After incubation the compounds were removed and fresh medium containing gentamicin was added to cell monolayers. Intracellular viable bacteria were determined $7 \mathrm{~h}$ after the infection step. Results are expressed as the percentage of cfu reduction by comparison with untreated controls. Data represent the average of five independent experiments performed in duplicate. Error bars represent SD. $\square$, Caco-2 cells treated with $20 \mathrm{mM} \mathrm{NH}_{4} \mathrm{Cl} ; \triangle$, Caco-2 cells treated with $0.1 \mu \mathrm{M}$ monensin; $O$, Caco- 2 cells treated with $0.1 \mu \mathrm{M}$ bafilomycin $\mathrm{A}_{1}$.
Untreated cells are shown in Fig. 3. At $1 \mathrm{~h}$ after infection, occasional bacteria $(<1$ bacteria/cell) were still in the process of entry (Fig. 3a) whereas cellassociated bacteria were intact and located within cell phagosomes (Fig. 3b); about 10 bacteria/cell were observed. After infection for $3 \mathrm{~h}$, most bacteria were free within the cytoplasm (Fig. 3c), demonstrating the ability of $L$. monocytogenes L37 to lyse the phagocytic vacuole membranes during the infective process. Intracytoplasmic bacteria appeared to be undamaged. Electron microscopy showed that intracellular movement and cell-to-cell spread occurred at this stage. Fig. 3d shows bacterial cells projecting into the neighbouring cells through a pseudopodium. Protrusion is limited by a double membrane.

Results obtained by treating $L$. monocytogenes-infected cells with bafilomycin $A_{1}$ are shown in Fig. 4. Fig. $4 \mathrm{a}$ shows the process of ingestion. After $1 \mathrm{~h}$ bacterial cells still appeared to be enclosed within a membrane-bound vacuole (Fig. 4b). This observation is in agreement with previous results obtained with inhibitors of vacuolar acidification showing that the inhibitory effect of these agents takes place after the process of entry. In contrast to the untreated cells, electron microscopy revealed that $3 \mathrm{~h}$ after infection, all bacteria remained enclosed within phagosomes. Many phagosomes had fused to form larger pockets in which dense lysosomal material could be observed (Fig. 4c) and the remaining micro-organisms were in the process of being degraded, as determined by breaks in the cell wall (Fig. 4d) or bacterial distortions.

\section{Discussion}

The usual in-vivo site of $L$. monocytogenes entry is the intestine. The mechanism of invasion of this microorganism has been clarified [6] by means of the human colon carcinoma cell line (Caco-2), which displays the remarkable property of expressing typical enterocytic differentiation under standard culture conditions.

Many pathogenic bacteria have the ability to invade host tissues by inducing their own endocytosis. Upon bacterial internalisation, generally, the newly formed phagosome is acidified by means of a protein pump ATPase and lysosomal enzymes are incorporated to form a degradative environment. Some bacteria remain entrapped in these compartments and are digested, whereas others have evolved a specialised strategy enabling them to escape into the cytoplasm and to multiply $[25,26]$.

The role of low $\mathrm{pH}$ in phagosome disruption by the exotoxin listeriolysin $\mathrm{O}$ is controversial. While it is accepted that listeriolysin $O$, necessary for the disruption of the phagosome membrane and intracellular growth of $L$. monocytogenes, is active only at 


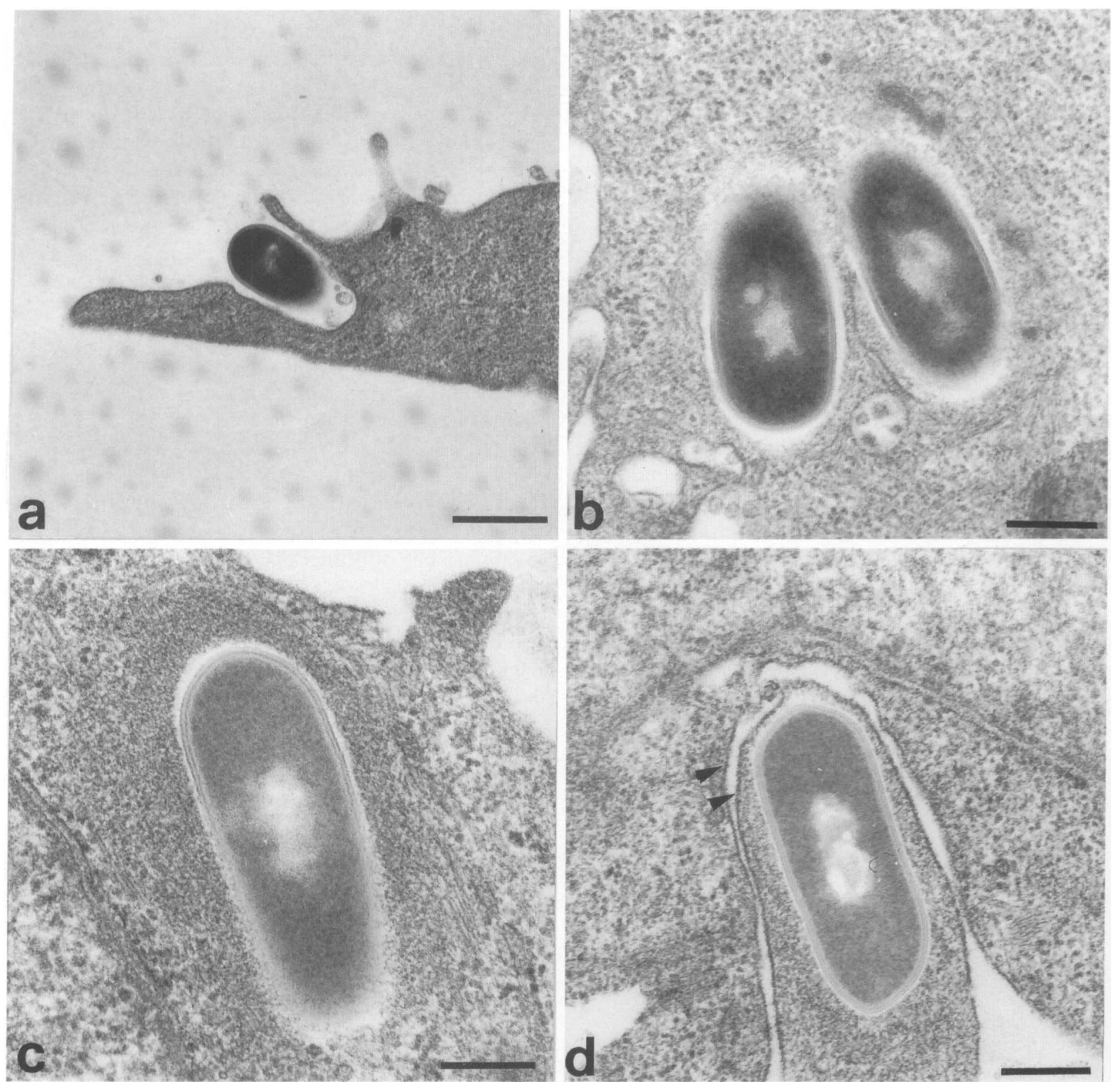

Fig. 3. Electron micrographs of thin sections of Caco-2 cells infected with L. monocytogenes. a, After infection for $1 \mathrm{~h}$ a few bacteria are still in the process of entry $(\mathrm{bar}=0.6 \mu \mathrm{m}) ; \mathrm{b}$, bacteria enclosed in phagosomal membrane (bar $=0.3 \mu \mathrm{m}) ;$ c, $3 \mathrm{~h}$ after invasion bacteria are free in cytoplasm $(\mathrm{bar}=0.24 \mu \mathrm{m})$; d, bacterium invading a neighbouring cell (transverse section of bacterium inside a pseudopodium); the membrane of the protrusion and the plasma membrane of the adjacent cell are both visible (arrowheads) (bar $=0.3 \mu \mathrm{m}$ ).

low $\mathrm{pH}$ of $5.5[15,16]$ and that the optimum for lysis of erythrocytes by listeriolysin $\mathrm{O}$ is $\mathrm{pH} 5.6$ [15], it has been reported that the weak base chloroquine does not prevent access of the bacterial cells to the cytoplasm and, in addition, haemolysin mutants are able to grow in some cell lines [17].

In this study an attempt was made to evaluate the role of vacuolar $\mathrm{pH}$ on the entry and growth of $L$. monocytogenes within enterocyte-like cells by use of different agents capable of raising the $\mathrm{pH}$ of intracellular acidic compartments. These agents, which readily enter the vesicles, have frequently been used to analyse the requirement of a low $\mathrm{pH}$ step during the entry of parasites [19]: $\mathrm{NH}_{4} \mathrm{Cl}$ is an 'acidotropic' weak base that accumulates in vesicles [20], monensin is a monovalent ion-selective ionophore that intercalates into membranes and mediates exchange of monovalent cations through the membrane thereby effecting a rise in vacuolar $\mathrm{pH}$ [21], and bafilomycin $A_{1}$ is a selective inhibitor of the vacuolar protonATPases [22]. Results showed that all these agents were capable of preventing the intracellular growth of L. monocytogenes. Experiments in which the compounds were present before, during and for different time periods after the infection step showed that this inhibition took place at an early stage of $L$. monocytogenes invasion of Caco- 2 cells: inhibition 


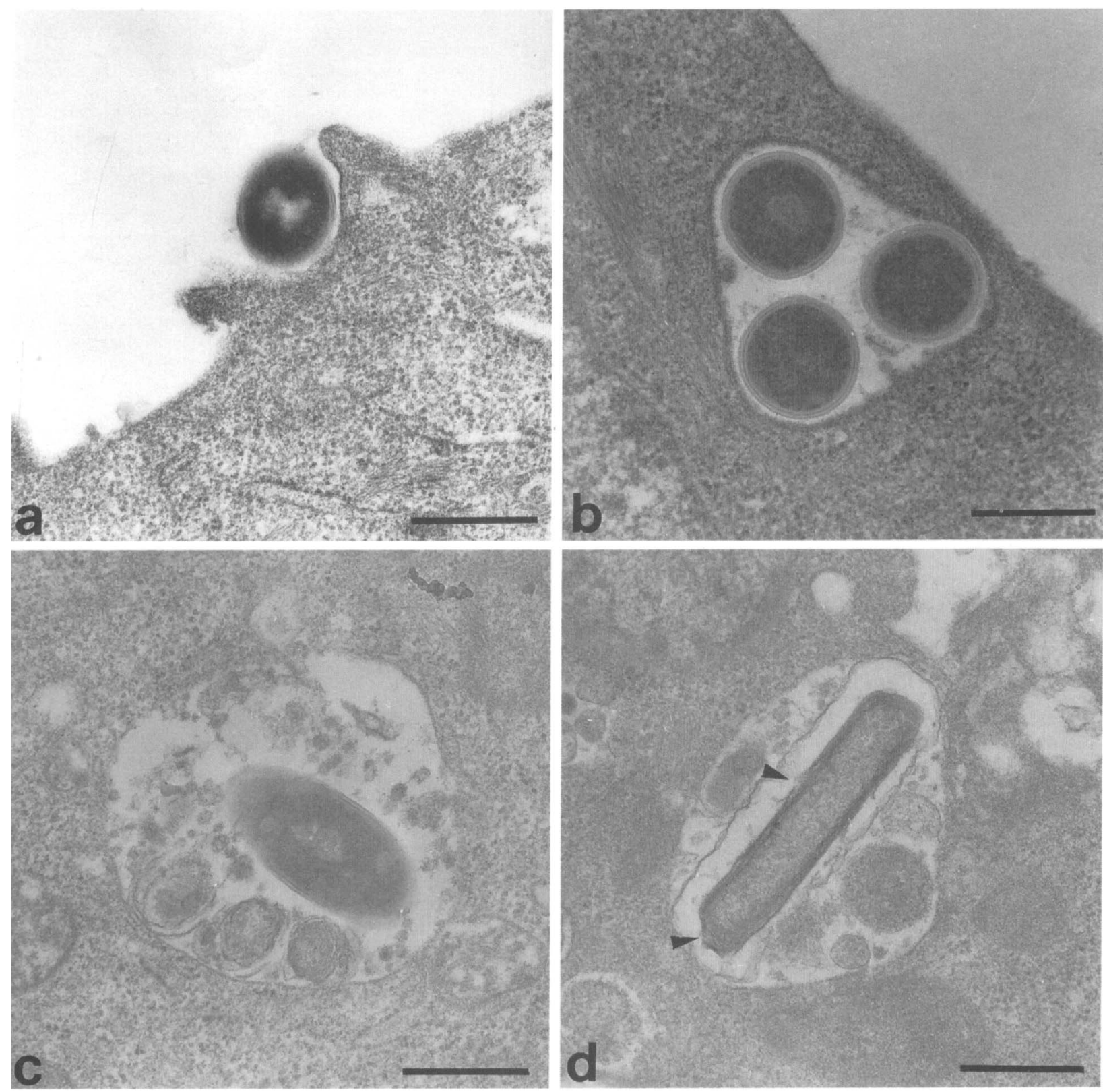

Fig. 4. Thin sections of bafilomycin $A_{1}$-treated L. monocytogenes-infected cells. a, Bacteria in the process of entry (bar $=0.5 \mu \mathrm{m}$ ); b, after incubation for $1 \mathrm{~h}$ bacterial cells appeared to be enclosed within a membrane-bound vacuole (bar $=0.4 \mu \mathrm{m})$; c, after infection for $3 \mathrm{~h}$ bacteria remained enclosed within a large phagosome in which dense lysosomal material is visible (bar $=0.5 \mu \mathrm{m}$ ); $\mathbf{d}$, one bacterium is under process of degradation and breaks in the cell wall are visible (arrowheads) (bar $=0.47 \mu \mathrm{m}$ ).

of bacterial growth had reached maximal values when the agents were present in the culture medium for $120 \mathrm{~min}$ after the infection step, suggesting that raising the intracellular vesicle $\mathrm{pH}$ influenced the delivery of bacteria from phagosomes.

To verify this hypothesis, the fate of $L$. monocytogenes in bafilomycin $\mathrm{A}_{1}$-treated and untreated Caco-2 cells was followed by transmission electron microscopy. In both experimental conditions, L. monocytogenes was able to invade the enterocyte-like cells, confirming that the inhibitory effect of bafilomycin $A_{1}$ took place after bacterial internalisation. Different events were observed after the infection step in untreated Caco-2 cells; release from the phagocytic vacuole allowed bacteria to escape phagolysosomal fusion and cell-tocell spread was observed, whereas in bafilomycin $A_{1}$ treated cells, bacteria initially remained enclosed within phagosomes and subsequently appeared in phagolysosomes. These findings confirm that inhibitors of vacuolar acidification prevent the escape of bacteria from the phagosome compartment and are consistent with the hypothesis that an acidic $\mathrm{pH}$ is necessary for listeriolysin $O$ to be active.

These agents represent a useful tool for the investigation of $\mathrm{pH}$ requirement in the endocytic pathways $[19,22]$ but as so far there have been only a few 
reports on their use in vivo, a choice between these different compounds for the potential treatment of $L$. monocytogenes infection will be possible only after an evaluation of their pharmacological properties in animal models.

This work was supported by Consiglio Nazionale Ricerche and Ministero Università Ricerca Scientifica Tecnologica grants. We thank Dr P. Aureli (ISS, Rome Italy) and Dr P. Cossart (IP, Paris France) for providing the $L$. monocytogenes $\mathrm{L} 37$ and the $L$. monocytogenes EGD strains, respectively.

\section{References}

1. Gellin BG, Broome CV. Listeriosis. JAMA 1989; 261: 13131320.

2. Schlech WF, Lavigne PM, Bortolussi RA et al. Epidemic listeriosis - evidence for transmission by food. $N$ Engl J Med 1983; 308: 203-206.

3. Farber JM, Peterkin PI. Listeria monocytogenes, a food-borne pathogen. Microbiol Rev 1991; 55: 476-511.

4. Cossart P, Mengaud J. Listeria monocytogenes. A model system for the molecular study of intracellular parasitism. $\mathrm{Mol}$ Biol Med 1989; 6: 463-474.

5. Portnoy DA, Chakraborty T, Goebel W, Cossart P. Molecular determinants of Listeria monocytogenes pathogenesis. Infect Immun 1992; 60: 1263-1267.

6. Gaillard J-L, Berche P, Mounier J, Richard S, Sansonetti P. In vitro model of penetration and intracellular growth of Listeria monocytogenes in the human enterocyte-like cell line Caco-2. Infect Immun 1987; 55: 2822-2829.

7. Dabiri GA, Sanger JM, Portnoy DA, Southwick FS. Listeria monocytogenes moves rapidly through the host-cell cytoplasm by inducing directional actin assembly. Proc Natl Acad Sci USA 1990; 87: 6068-6072.

8. Dramsi S, Kocks C, Forestier C, Cossart P. Internalin-mediated invasion of epithelial cells by Listeria monocytogenes is regulated by the bacterial growth state, temperature and the pleiotropic activator prfA. Mol Microbiol 1993; 9: 930-941.

9. Gaillard J-L, Berche P, Frehel C, Gouin E, Cossart P. Entry of $L$. monocytogenes into cells is mediated by internalin, a repeat protein reminiscent of surface antigens from gram-positive cocci. Cell 1991; 65: 1127-1141.

10. Mengaud J, Chenevert J, Geoffroy C, Gaillard J-L, Cossart P. Identification of the structural gene encoding the SH-activated hemolysin of Listeria monocytogenes: listeriolysin $\mathrm{O}$ is homologous to streptolysin $\mathrm{O}$ and pneumolysin. Infect Immun 1987; 55: 3225-3227.

11. Cossart P, Vicente MF, Mengaud J, Baquero F, Perez-Diaz JC, Berche $\mathrm{P}$. Listeriolysin $\mathrm{O}$ is essential for virulence of Listeria monocytogenes: direct evidence obtained by gene complementation. Infect Immun 1989; 57: 3629-3636.

12. Bielecki J, Youngman P, Connelly P, Portnoy DA. Bacillus subtilis expressing a haemolysin gene from Listeria monocytogenes can grow in mammalian cells. Nature 1990; 345: 175-176.

13. Tilney LG, Portnoy DA. Actin filaments and the growth, movement, and spread of the intracellular bacterial parasite, Listeria monocytogenes. J Cell Biol 1989; 109: 1597-1608.

14. Mounier J, Ryter A, Coquis-Rondon M, Sansonetti PJ Intracellular and cell-to-cell spread of Listeria monocytogenes involves interaction with $\mathrm{F}$-actin in the enterocytelike cell line Caco-2. Infect Immun 1990; 58: 1048-1058.

15. Geoffroy C, Gaillard J-L, Alouf JE, Berche P. Purification, characterization, and toxicity of the sulphydryl-activated hemolysin listeriolysin $\mathrm{O}$ from Listeria monocytogenes. Infect Immun 1987; 55: 1641-1646.

16. De Chastellier C, Berche P. Fate of Listeria monocytogenes in murine macrophages: evidence for simultaneous killing and survival of intracellular bacteria. Infect Immun 1994; 62: 543 553.

17. Portnoy DA, Sun AN, Bielecki J. Escape from the phagosome and cell-to-cell spread of Listeria monocytogenes. In: Hook M, Switalski L (eds) Microbial adhesion and invasion. New York, Springer-Verlag. 1992: 89.

18. Portnoy DA, Tweten RK, Kehoe M, Bielecki J. Capacity of listeriolysin $O$, streptolysin $O$, and perfringolysin $O$ to mediate growth of Bacillus subtilis within mammalian cells. Infect Immun 1992; 60: 2710-2717.

19. Mellman I. Fuchs R, Helenius A. Acidification of the endocytic and exocytic pathways. Annu Rev Biochem 1986; 55: $663-700$

20. Poole B, Ohkuma S. Effect of weak bases on the intralysosomal pH in mouse peritoneal macrophages. J Cell Biol 1981; 90: $665-669$.

21. Nakazato K, Hatano Y. Monensin-mediated antiport of $\mathrm{Na}^{+}$ and $\mathrm{H}^{+}$across liposome membrane. Biochim Biophys Acta 1991; 1064: 103-110.

22. Yoshimori T, Yanamoto A, Moriyama Y, Futai M, Tashiro Y. Bafilomycin $A_{1}$, a specific inhibitor of vacuolar-type $\mathrm{H}^{+}$. ATPase, inhibits acidification and protein degradation in lysosomes of cultured cells. J Biol Chem 1991; 266: 1770717712.

23. Conte MP, Longhi C, Petrone G, Polidoro M, Valenti P, Seganti L. Listeria monocytogenes infection of Caco-2 cells: role of growth temperature. Res Microbiol 1994; 145: 677-682.

24. Conte MP, Mastromarino P, Nicoletti M, Visca P, Valenti $P$, Seganti L. Effect of polyelectrolytes on entry of Escherichia coli HB101(pRI203) into HeLa cells. Microb Pathog 1990; 9: 191-198.

25. Falkow S. Bacterial entry into eukaryotic cells. Cell 1991; 65 : 1099-1102.

26. Wick MJ, Madara JL, Fields BN, Normark SJ. Molecular cross talk between epithelial cells and pathogenic microorganisms. Cell 1991; 67: 651-659. 